Original Article

\title{
STATISTICAL AND KINETIC STUDIES OF ACID PROTEASE BY ASPERGILLUS SPP. ISOLATED FROM SOIL CONTAMINATED WITH ABATTOIR WASTE
}

\author{
RADHA S. ${ }^{1}$, SRIDEVI A. ${ }^{2}$, PRASAD NBL ${ }^{3}$, NARASIMHA G. ${ }^{4}$
}

1Department of Biotechnology, Sree Vidyanikethan Engg. College, Tirupati, ${ }^{2}$ Department of Microbiology, Mahila University, Tirupati, Andhra Pradesh, 3JNTUA, OTPRI, Ananthapuramu, Andhra Pradesh, India, ${ }^{4}$ Applied Microbiology Lab, Department of Virology, Sri Venkateswara University, Tirupati, Andhra Pradesh

Email: dr.g.narasimha@gmail.com

Received: 16 Oct 2017 Revised and Accepted: 21 Dec 2017

\section{ABSTRACT}

Objective: Aim of the present investigation was to optimize the acid protease production from Aspergillus spp. through statistical method in solid state fermentation and to study the inhibitory enzyme kinetics.

Methods: To fulfill above mentioned aim, seven solid substrates were screened though using PBD (Plackett-Burman Design) and concentrations of three significant were determined by using one of the Response surface methodologies (RSM), Box-Behnken design (BBD). Inhibitory enzymatic effects were carried by using previously developed models.

Results: From PBD, wheat bran, soybean meal, and dried potato peel (DPP) were screened as major influencing nutritional factors for enzyme production. Better optimal values were determined by BBD as wheat bran: $8.841 \mathrm{~g}$, soybean meal: $4.557 \mathrm{~g}$, and DPP: $0.661 \mathrm{~g}$ with predicted protease activity as $817.83 \mathrm{U} / \mathrm{g}( \pm 44.047 \mathrm{U} / \mathrm{g})$. Linear, interactive, and quadratic effects of aforesaid substrates on enzyme activity were formulated by quadratic model through multiple regression model $\left(\mathrm{R}^{2}\right.$ Adj: Adjusted $\mathrm{R}$ square $=94.78 \%$; $\mathrm{R}^{2}$ Pre: Predicted $\mathrm{R}$ square $\left.=98.13 \%\right)$. Partial substrate inhibition to crude acid protease activity was notified with casein concentration higher than 0.4 mmol and inhibitory constant, $\mathrm{K}_{\mathrm{N}}$, was computed with previous developed mathematical models. Ratio of reaction rate constants, $\mathrm{k}_{4} / \mathrm{k}_{2}$, was found to be 0.233 that had confirmed partial casein inhibition to enzyme velocity. Improved activity and kinetics of caseinolysis make amicable for industrial applications.

Conclusion: Quick optimization was performed with statistical methodology over conventional approach. Inhibitory enzyme kinetic studies were important for industrial applications of acid protease.

Keywords: Acid protease, Optimization, Statistical methodology, Casein inhibition, Reaction velocity

(C) 2018 The Authors. Published by Innovare Academic Sciences Pvt Ltd. This is an open access article under the CC BY license (http://creativecommons.org/licenses/by/4.0/) DOI: http://dx.doi.org/10.22159/ijpps.2018v10i2.23165

\section{INTRODUCTION}

Proteases (E. C.3.4.21-25) catalyze proteolysis which are most industrially important hydrolases $[1,2]$. Contribution of these enzymes to total enzyme sales is about $60 \%$ due to their exploitation in pharmaceutical, detergent, leather, and food industries $[3,4]$. The increasing trend of microbial protease in pharmaceutical applications was summarized by [1]. Especially acid proteases from fungal species have promised applications in pharmaceutical, cheese, meat processed, baking, and soy sauce industries [5-7]. Moreover these are function as therapeutic agents in development of declotting and anti-inflammatory, antimicrobial activities [5-7]. Mainly species of Mucor, Aspergillus, Penicillium, and Rhizopus are being capable of producing acid proteases $[3,8,9]$.

Designing of suitable fermentation medium with economic concern is a challenge as it affects the product yield and it can be achieved through optimization techniques [10]. Several classical (OVAT: One variable at a time) and statistical methodologies are available for fermentation optimization [11]. In OVAT approach, one variable is changed by keeping others as constants which is a tedious method as it requires more number of experimental runs and ignores the interactions among selected parameters of fermentation [12, 13]. However, statistical methods establish a systematic relationship between input and output of fermentation to eliminate the drawbacks of classical approach $[14,15]$.

Substrate inhibitory studies are common in many enzymatic reactions as rate of reactions are inhibited by excess substrate which are crucial in the design of enzyme reactors and also in regulation of metabolic pathways [16-18]. Availability of literature on acid protease optimization and also on studies at substrate inhibitory level for enzymatic reactions is scanty. Therefore the present investigation was performed to identify the significant solid substrates for acid protease production from fungi, Aspergillus spp. using PBD (Plackett-Burman design) and to find out the optimum combination of screened substrates through BBD (Box-Behnken design) in solid state fermentation (SSF). Further study was extended to analyze the casein inhibition on initial velocity of crude protease through various kinetic models.

\section{MATERIALS AND METHODS}

\section{Materials}

Wheat bran and soybean meal were obtained from local market Potato peel was collected from kitchen waste and allowed to air dried. Remaining chemicals were of analytical grade (Hi-Media).

\section{Screening of solid substrates}

In the present work, Plackett-Burman design was summarized in table 1 and individual combination of fermentation medium was represented by each row. According to PBD design the fermentation media were prepared with composition of seven selected substrates. The frequencies of high (Coded as +1 ) level runs are same as that of low (-1) level runs (table-1). Then Erlenmeyer flasks with specified medium were moistened with $60 \%(\mathrm{v} / \mathrm{w})$ salt mineral solution of composition: in (g/l) $\mathrm{K}_{2} \mathrm{HPO}_{4} 1, \mathrm{KH}_{2} \mathrm{PO}_{4} 3, \mathrm{Mg}_{2} \mathrm{SO}_{4} 1$, and $\mathrm{CaCl}_{2} 0.1$ and $\mathrm{ZnSO}_{4}$ 0.01. Fungal spore Inoculum was prepared from the stock culture of Aspergillus spp. isolated from soil contaminated with abattoir waste [19]. Later sterilized medium was inoculated with $10 \%$ $(\mathrm{v} / \mathrm{w})$ fungal spore suspension. Then the contents of the flasks were mixed thoroughly and incubated at room temperature for $120 \mathrm{~h} \mathrm{(5 \textrm {d } )}$ with an initial $\mathrm{pH}$ of 6.0 . Crude protease was extracted by adding $50 \mathrm{ml}$ of distilled water to flask, mixing at $150 \mathrm{rpm}$ at room temperature for an hour. After incubation the dry weight of fungal biomass and 
protease activity was performed [19]. Unit of protease was defined as liberation of one microgram of tyrosine from substrate per minute and the acid protease activity was expressed as $\mathrm{U} / \mathrm{g}$ solid substrate. Protein content in the fungal filtrate was analyzed [20].

The regression analysis was employed to the best of experimental data through a first order linear model as follows:

$$
Y_{P}=\beta_{0}+\sum_{i=1}^{7} \beta_{i} X_{i}
$$

Where Yp: Predicted protease activity, $\mathrm{X}_{\mathrm{i}}$ : Coded settings for seven substrates, $\beta_{0}$ : Model intercept, $\beta_{\mathrm{i}}$ : Linear coefficients of model

\section{Optimization of significant substrates through Box-Behnken design}

Based on PBD results, amounts of key factors wheat bran, soybean meal, and dried potato peel (DPP) were optimized by BBD which includes three levels as low ( -1$)$, center point (' 0 '), and high settings ('+'). Fermentation medium was prepared as per table 3 and SSF and analysis was carried as described above. Design matrix (table 3) consists of three blocks with each block corresponds to four rows and three central runs at the end in a total of 15 experiments. In the first block, wheat bran and soybean meal were kept at low and high levels that corresponds to $2^{2}$ matrix while DPP is kept at its center value. In a similar way, soybean meal is at center point in the second block while wheat bran is made as center in third block. A second order polynomial equation, fitted to data by multiple regression procedure, resulted in quadratic model as follows:

$$
Y=\beta_{0}+\sum_{i=1}^{3} \beta_{i} X_{i}+\sum_{i=1}^{2} \sum_{j=i+1}^{3} \beta_{i j} X_{i} X_{j}+\sum_{i=1}^{3} \beta_{i i} X_{i}^{2}
$$

Y-Predicted response, $X_{1}-$ Wheat bran, $X_{2}$-Soybean meal, $X_{3}-D P P, \beta_{0}$ Value of fitted response at the center point of the design, $\beta_{i}$-Independent terms, $\beta_{\mathrm{ij}}$-Interaction coefficients, $\beta_{\mathrm{ii}}$-Quadratic coefficients

\section{Kinetics of casein inhibition}

In order to study the enzyme activity as a function of casein amount, experiments were performed with substrate concentration range from 0.1 to $2.2 \mathrm{mmol}$. Resulted data were tried to fit to below mentioned mathematical models of substrate inhibition (SI) with the following reaction mechanism:

$$
\begin{gathered}
\mathrm{E}+\mathrm{S} \stackrel{\mathrm{K}_{1}}{\leftrightarrow} \mathrm{E} . \mathrm{S} \stackrel{\mathrm{k}_{2}}{\rightarrow} \mathrm{E}+\mathrm{P} \\
+ \\
\text { S.E. } \stackrel{\mathrm{k}_{4}}{\rightarrow} \mathrm{E}+\mathrm{S}+\mathrm{P}------(3)
\end{gathered}
$$

(Above reaction mechanism, Eq.3, was adopted from previous studies $[16,21,22])$.

Where [S]: Substrate concentration; E: Enzyme; P: Product

E. S: Enzyme-Substrate complex; S. E. S: Substrate-EnzymeSubstrate complex.

V: Velocity of reaction; Vmax: Maximum reaction velocity
$\mathrm{K}_{1}$ and $\mathrm{K}_{\mathrm{N}}$ : Dissociation constants for E. S and S. E. S complexes $\mathrm{k}_{2}$ and $\mathrm{k}_{4}$ : Reaction rate constants

Model 1 (Andrew's model [21])

The assumption of rapid equilibrium yields

$$
\mathrm{V}=\frac{\mathrm{V}_{\max }[\mathrm{S}]}{\left.\mathrm{K}_{1}+[\mathrm{S}]+\mathrm{I}^{2}\right]^{2} / \mathrm{K}_{\mathrm{N}}}
$$

At low substrate concentrations, $\frac{[S]^{2}}{K_{N}} \ll 1$, and inhibition effect was not observed and velocity was

$$
\mathrm{V}=\frac{\mathrm{V}_{\max }}{1+\mathrm{K}^{1 /[S]}}
$$

At high casein concentrations, $\mathrm{K}_{1} /[\mathrm{S}]<<1$, the rate in this case was

$$
\mathrm{V}=\frac{\mathrm{V}_{\max }}{1+{ }^{[S]} / \mathrm{K}_{\mathrm{N}}}
$$

Model II: (Adopted from [18])

$$
\frac{\left(V_{\max }-V\right)}{\mathrm{V}}=\frac{[\mathrm{S}]\left(1-{ }^{\mathrm{k}_{4}} / \mathrm{k}_{2}\right)}{\left.\mathrm{K}_{\mathrm{N}}+[\mathrm{S}]\right]_{\mathrm{k}}}
$$

\section{RESULTS AND DISCUSSION}

Current investigation was focused on easy way of the design of fermentation medium with inexpensive nutritional variables for optimization of extracellular acid protease production through SSF by Aspergillus spp. The use of quadratic response surface models makes the method much simpler than standard nonlinear techniques for determining optimal designs [10,23].

\section{Identification of influenced substrates through two-level PBD}

Minimal and maximal response was observed as 54.12 and $307.30 \mathrm{U} / \mathrm{g}$ from selected carbon and nitrogen sources (table 1 and 2) through screening method. Discrimination between significant and nonsignificant substrates were based upon the calculated values of main effect and probability values (P-value) [24] which were summarized in table 2. Among the tested substrates, ${ }^{*} \mathrm{P} \leq 0.01$ revealed that wheat bran (Main carbon source), soybean meal (Main nitrogen source), and DPP (Additional carbon source) induced microbial growth as well as biocatalyst activity. However, negativity in enzyme production was observed with corn flour as it was in fourth place therefore it could not select for response surface methodology (RSM).

The remaining substrates groundnut meal, rice flour, and cracked wheat were neglected for further optimization studies as ${ }^{*} \mathrm{P}>0.01$. Same authors optimized several physical, chemical, and nutritional parameters for the same enzyme from the same fungal culture through OVAT and revealed that cracked wheat was the preferable

\begin{tabular}{|c|c|c|c|c|c|c|c|c|}
\hline \multirow[t]{2}{*}{ Trial } & \multicolumn{7}{|c|}{ Carbon and nitrogen sources } & \multirow[b]{2}{*}{$\begin{array}{l}\text { Observed Protease } \\
\text { activity }(\mathrm{U} / \mathrm{g})\end{array}$} \\
\hline & $\begin{array}{l}\mathrm{X}_{1} \\
\text { Wheat bran }\end{array}$ & $\begin{array}{l}\mathrm{X}_{2} \\
\text { Cracked wheat }\end{array}$ & $\begin{array}{l}\mathrm{X}_{3} \\
\text { Groundnut meal }\end{array}$ & $\begin{array}{l}\mathrm{X}_{4} \\
\text { Soybean meal }\end{array}$ & $\begin{array}{l}\mathrm{X}_{5} \\
\text { Corn flour }\end{array}$ & $\begin{array}{l}\mathrm{X}_{6} \\
\text { Dried potato peel }\end{array}$ & $\begin{array}{l}X_{7} \\
\text { Rice flour }\end{array}$ & \\
\hline $\mathrm{R}_{1}$ & $+1(10)$ & $+1(10)$ & $-1(0.5)$ & $+1(5)$ & $-1(2.5)$ & $+1(1.0)$ & $-1(0.5)$ & 307.32 \\
\hline $\mathrm{R}_{2}$ & $-1(5.0)$ & $+1(10)$ & $+1(1.0)$ & $-1(2.5)$ & $+1(5)$ & $+1(1.0)$ & $-1(0.5)$ & 61.76 \\
\hline $\mathrm{R}_{3}$ & $-1(5.0)$ & $+1(10)$ & $+1(1.0)$ & $+1(5.0)$ & $-1(2.5)$ & $-1(0.5)$ & $+1(1.0)$ & 115.06 \\
\hline $\mathrm{R}_{4}$ & $+1(10)$ & $-1(5.0)$ & $+1(1.0)$ & $+1(5.0)$ & $+1(5.0)$ & $-1(0.5)$ & $-1(0.5)$ & 160.56 \\
\hline $\mathrm{R}_{5}$ & $-1(5.0)$ & $-1(5.0)$ & $-1(0.5)$ & $+1(5.0)$ & $+1(5.0)$ & $+1(1.0)$ & $+1(1.0)$ & 143.82 \\
\hline $\mathrm{R}_{6}$ & $+1(10)$ & $+1(10)$ & $-1(0.5)$ & $-1(2.5)$ & $+1(5.0)$ & $-1(0.5)$ & $+1(1.0)$ & 81.40 \\
\hline $\mathrm{R}_{7}$ & $+1(10)$ & $-1(5.0)$ & $+1(1.0)$ & $-1(2.5)$ & $-1(2.5)$ & $+1(1.0)$ & $+1(1.0)$ & 176.22 \\
\hline $\mathrm{R}_{8}$ & $-1(5.0)$ & $-1(5.0)$ & $-1(0.5)$ & $-1(2.5)$ & $-1(2.5)$ & $-1(0.5)$ & $-1(0.5)$ & 54.12 \\
\hline
\end{tabular}
main carbon source to wheat bran [25]. Comparison between OVAT and PBD revealed that wheat bran was the more effective carbon source when it was supplemented with various combinations of other substrates as it was missing with non-statistical method. Based upon observations of two approaches viz., OVAT reported by [25] and the present investigation, conventional approach had led to wrong conclusions as suggested by [6].

Table 1: Solid substrates with coded settings and actual concentrations $(\% \mathrm{w} / \mathrm{w})$ with response of fermentation for PBD

*R1-R8 represented eight different fermentations; *Values in table-were represented as mean of two trials, *Amount of each substrate was measured in grams. 
Table 2: Calculation of main effects using MS excel-7 and Identification of significant and non-significant substrates from results of PBD for biocatalyst production

\begin{tabular}{llll}
\hline Factor & Main effect & Standard error & P value \\
\hline Wheat bran $\left(X_{1}\right)$ & $\mathbf{4 3 . 8 4}$ & 7.50 & $<\mathbf{0 1}$ (Significant) \\
Cracked wheat $\left(\mathrm{X}_{2}\right)$ & 3.85 & 8.78 & 0.70 (Non-Significant) \\
Groundnut meal $\left(\mathrm{X}_{3}\right)$ & -9.13 & 6.54 & 0.29 (Non-Significant) \\
Soybean meal $\left(\mathrm{X}_{4}\right)$ & $\mathbf{4 4 . 1 5}$ & 7.50 & $<0.01$ (Significant) \\
Corn flour $\left(\mathrm{X}_{5}\right)$ & -25.64 & 7.50 & $<0.05$ (Non-Significant) \\
Dried potato peel $\left(\mathrm{X}_{6}\right)$ & $\mathbf{3 4 . 7 4}$ & 7.50 & $\leq 0.01$ (Significant) \\
Rice flour $\left(\mathrm{X}_{7}\right)$ & -8.41 & 7.00 & 0.35 (Non-Significant) \\
\hline
\end{tabular}

Fitness of experimental data to following proposed linear model for the present biocatalyst production was evaluated through regression analysis at $99 \%$ confidence level $\left({ }^{*} \mathrm{P} \leq 0.01\right)$ and it was formulated in Eq. (8)

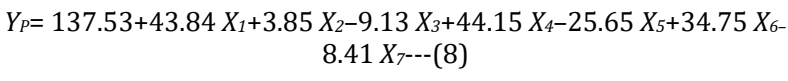

Predicted activity of biocatalyst, $Y_{p}$, was computed from Eq. (8) and the less deviation of predicted data from experimental activity was observed since the regression coefficient was 99.88\% (Fig.1). PBD could provide significant variables but not the optimal quantity of each substrate for optimum enzyme production as it ignores interactive effects of substrates as it had given an idea about potent nutritional variables from examined substrates.

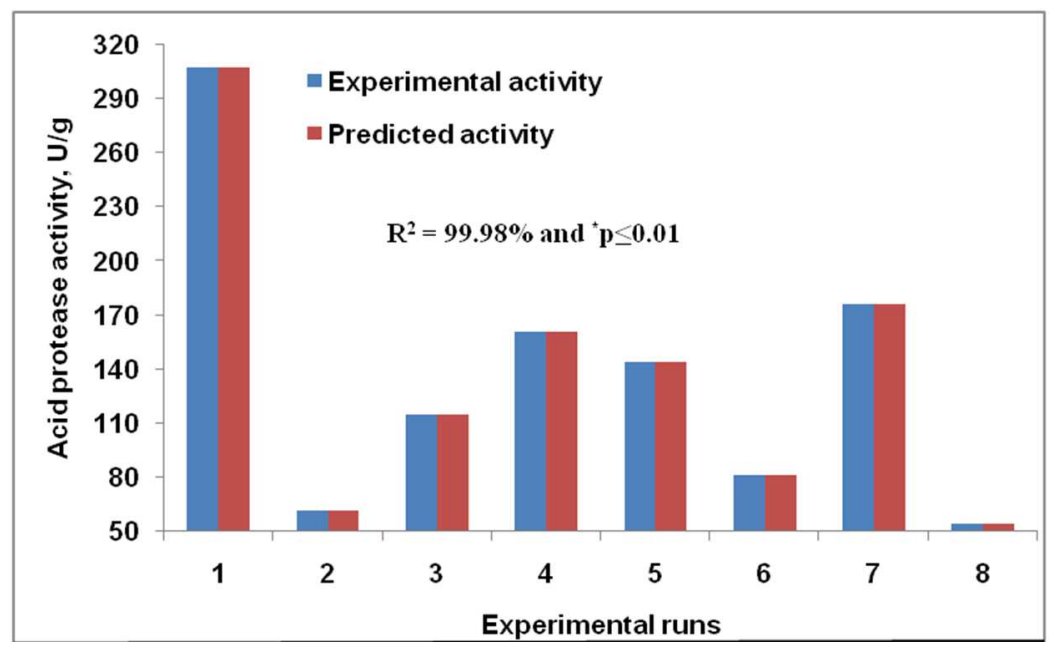

Fig. 1: Depiction of experimental and predicted acid protease activity using plackett-burman design of experiments

\section{Prediction of optimal combination through box-behnken design}

Evaluation of screened nutritional factors at three levels $(-1,0,+1)$ was much useful in achieving the maximum productivity of protease. With BBD of keyfactors, the minimum and maximum protease activities were observed as 121.59 and $807.83 \mathrm{U} / \mathrm{g}$ (table 3). Biomass prediction was estimated from Eq.10.

Production of enzyme solely was a function of growth of Aspergillus spp. so that the profile of fungal biomass was shown in fig. 2 .

Table 3: Box-behnken design for three substrates with coded values with observed and predicted enzyme activity from Aspergillus spp. in SSF

\begin{tabular}{|c|c|c|c|c|c|}
\hline \multirow[t]{2}{*}{ Trial } & \multirow{2}{*}{$\begin{array}{l}\text { Wheat bran } \\
\mathrm{X}_{1}\end{array}$} & \multirow{2}{*}{$\begin{array}{l}\text { Soybean meal } \\
\mathrm{X}_{2}\end{array}$} & \multirow{2}{*}{$\begin{array}{l}\text { Dried potato peel } \\
X_{3}\end{array}$} & \multicolumn{2}{|c|}{ Acid protease activity (U/g) } \\
\hline & & & & Mean experimental & Predicted \\
\hline 1 & $-1(5.00)$ & $-1(2.50)$ & $0(0.75)$ & 109.08 & 121.59 \\
\hline 2 & $-1(5.00)$ & $1(5.00)$ & $0(0.75)$ & 213.26 & 237.77 \\
\hline 3 & $1(10.0)$ & $-1(2.50)$ & $0(0.75)$ & 525.4 & 500.94 \\
\hline 4 & $1(10.0)$ & $1(5.00)$ & $0(0.75)$ & 747.07 & 734.6 \\
\hline 5 & $-1(5.00)$ & $0(3.75)$ & $-1(0.50)$ & 119.08 & 140.83 \\
\hline 6 & $-1(5.00)$ & $0(3.75)$ & $1(1.00)$ & 339.21 & 280.57 \\
\hline 7 & $1(10.0)$ & $0(3.75)$ & $-1(0.50)$ & 687.05 & 745.75 \\
\hline 8 & $1(10.0)$ & $0(3.75)$ & $1(1.00)$ & 573.49 & 552.9 \\
\hline 9 & $0(7.50)$ & $-1(2.50)$ & $-1(0.50)$ & 417.28 & 383.11 \\
\hline 10 & $0(7.50)$ & $-1(2.50)$ & $1(1.00)$ & 271.31 & 317.53 \\
\hline 11 & $0(7.50)$ & $1(5.00)$ & $-1(0.50)$ & 565.72 & 541.17 \\
\hline 12 & $0(7.50)$ & $1(5.00)$ & $1(1.00)$ & 496.71 & 530.98 \\
\hline 13 & $0(7.50)$ & $0(3.75)$ & $0(0.75)$ & 807.83 & 807.83 \\
\hline 14 & $0(7.50)$ & $0(3.75)$ & $0(0.75)$ & 807.80 & 807.83 \\
\hline 15 & $0(7.50)$ & $0(3.75)$ & $0(0.75)$ & 807.80 & 807.83 \\
\hline
\end{tabular}

*Values in above table were represented as mean of two trials, ${ }^{*}$ Amount of each substrate was measured in grams, $* \mathrm{R}^{2}$ Adj $($ Adjusted $\mathrm{R}$ square $)=$ 94.78\%; R² $\operatorname{Pre}$ (Predicted R square) $=98.13 \%$ 


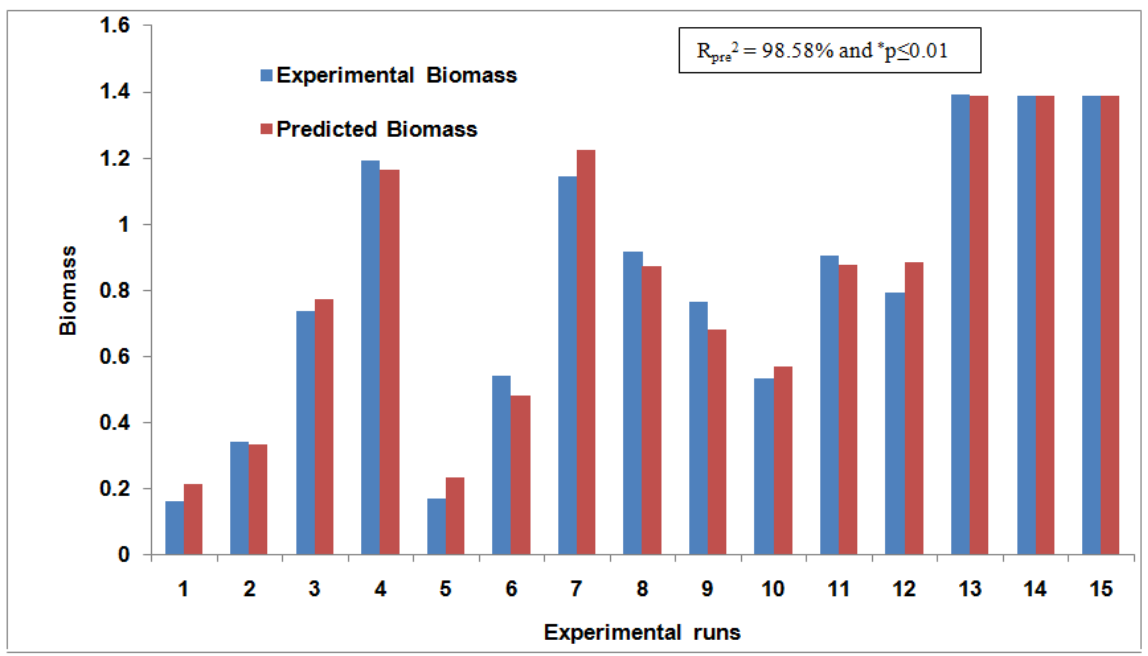

Fig. 2: Plot showing experimental and predicted mass of Aspergillus spp. with Box-Behnken approach

Scattered data obtained from 15 experimental runs was depicted in response surface plot in fig. 3. Surface plot fairly indicated a general increase in model response as concentrations of wheat bran and soybean meal increased from their center (' 0 ') to higher
('+') values. Interactions among selected carbon and nitrogen sources were depicted in fig. 4 to 6 with respective slices of DPP (fig. 4a), soybean meal (fig. 5a), and wheat bran (fig. 6a) in three dimensional form.

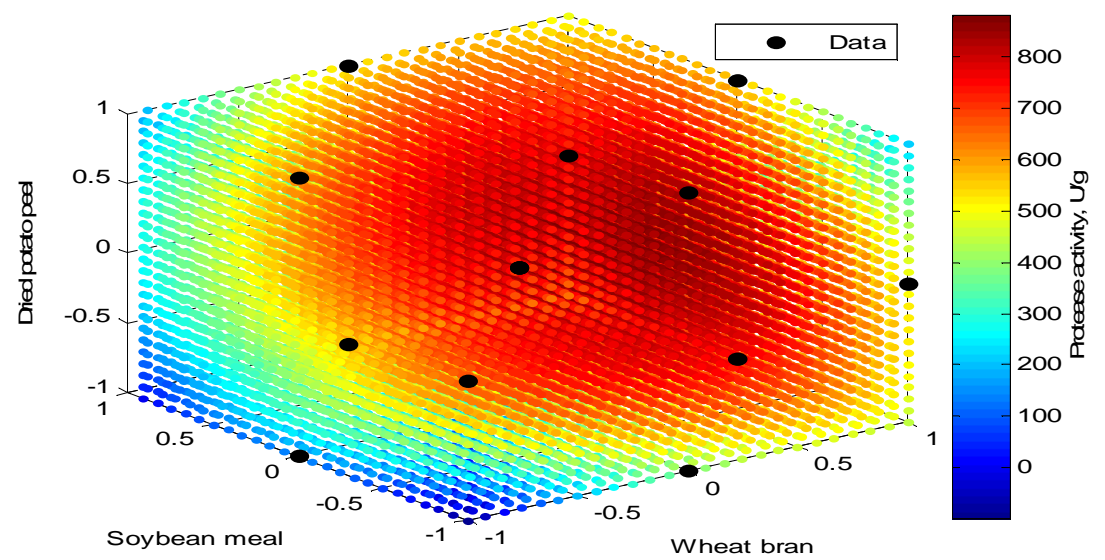

Fig. 3: Three dimensional plot depicting quadratic response surface model with three axes as wheat bran $(5-10 \% \mathrm{w} / \mathrm{w})$, soybean meal $(2.5-5 \% \mathrm{w} / \mathrm{w})$, and dried potato peel $(0.5-1.0 \% \mathrm{w} / \mathrm{w})$

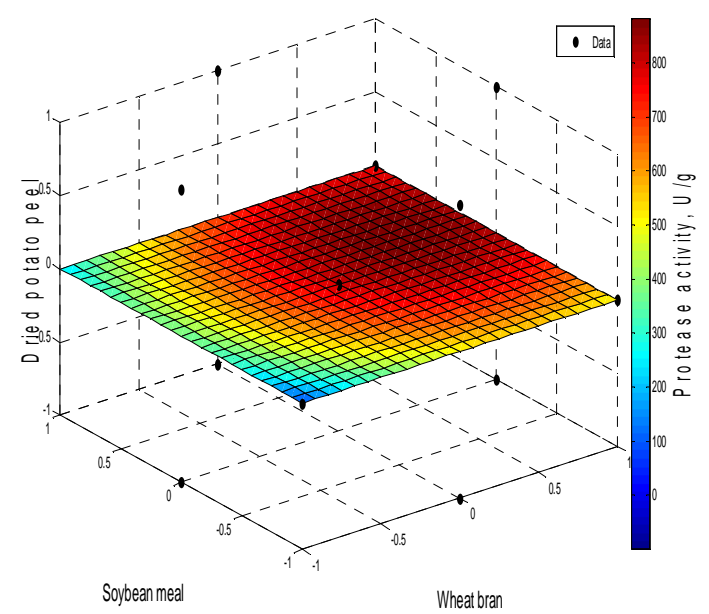

(a)

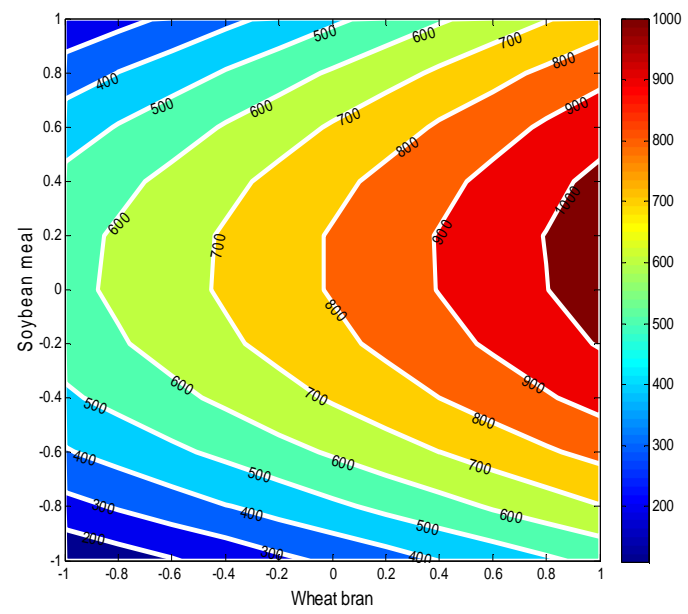

(b)

Fig. 4: Two-way interactions between wheat bran and soybean meal with $0.75 \%(w / w)$ of DPP, (a) Three dimensional plot and (b) Contour diagram with predicted enzyme activity range, from 150 to $975 \mathrm{U} / \mathrm{g}$ 


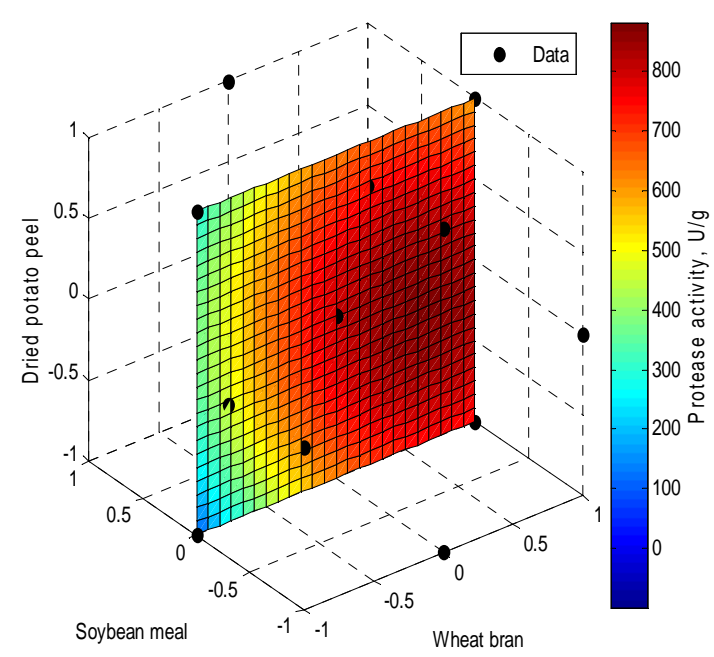

(a)

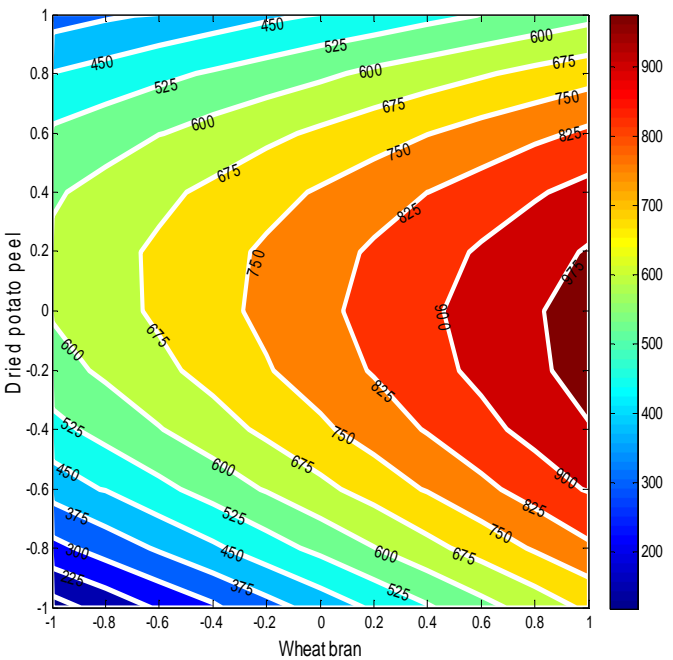

(b)

Fig. 5: Two-way interactions between wheat bran and DPP with soybean meal fixed at $3.75 \% \mathrm{w} / \mathrm{w}$ (a) Three dimensional plot and (b) Contour diagram with predicted enzyme activity range 150 to $975 \mathrm{U} / \mathrm{g}$

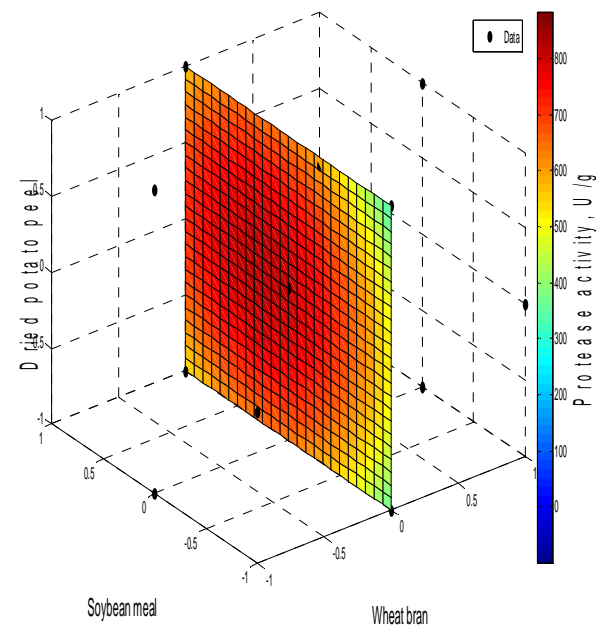

(a)

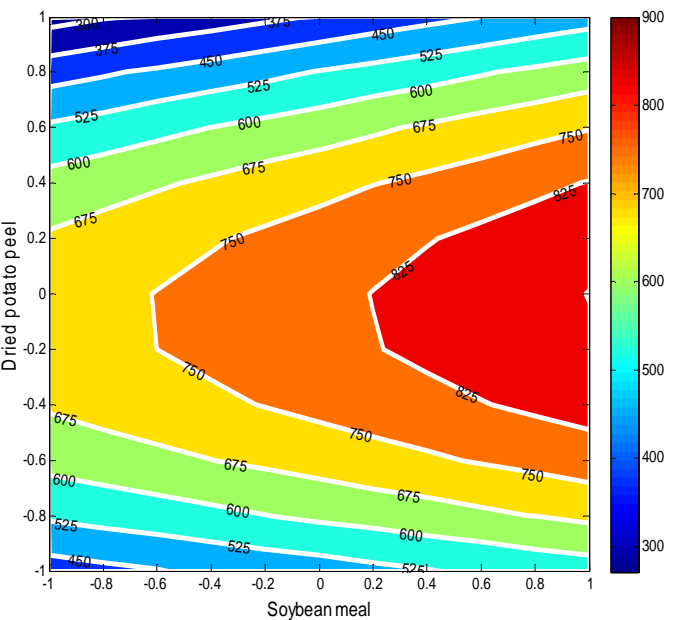

(b)

Fig. 6: Interactions between soybean meal and DPP with wheat bran at 7.5\% (w/w) (a) 3-D plot and (b) Contour diagram with covered range of enzyme activity 450-825 $\mathrm{U} / \mathrm{g}$

Minimum to maximum predicted enzyme activity was noticed as 150 and $975 \mathrm{U} / \mathrm{g}$ from contour diagrams. Optimum combination of substrates (Wheat bran: $8.841 \mathrm{~g}$, Soybean meal: $4.557 \mathrm{~g}$, and DPP: $0.661 \mathrm{~g}$ ) was achieved through predicted plot of full quadratic model $\left({ }^{*} \mathrm{p} \leq 0.01\right)$ with the acid protease activity of $817.83 \mathrm{U} / \mathrm{g}( \pm 44.047$ $\mathrm{U} / \mathrm{g}$ ). The coefficients of second order polynomial model for the prediction of enzyme activity (table 4) and for biomass were determined by using ANOVA (Analysis of ariance) and the proposed models were as follows:

\section{Predicted acid protease activity:}

$\mathrm{Y}_{\text {Protease activity }}=807.83+219.04 \mathrm{X}_{1}+87.46 \mathrm{X}_{2}-13.55 \mathrm{X}_{3} / /$ linear effects

$+29.37 \mathrm{X}_{1} \mathrm{X}_{2}-83.42 \mathrm{X}_{1} \mathrm{X}_{3}+19.24 \mathrm{X}_{2} \mathrm{X}_{3} / /$ Interactive effects

-208.573 $\mathrm{X}_{1}{ }^{2}-200.525 \mathrm{X}_{2}{ }^{2}-169.52 \mathrm{X}_{3}{ }^{2} / /$ Quadratic effects (9)

\section{Predicted mass of Aspergillus spp.:}

$\mathrm{Y}_{\text {Biomass }}=1.393+0.348 \mathrm{X}_{1}+0.129 \mathrm{X}_{2}-0.026 \mathrm{X}_{3} / /$ linear effects

$+0.068 \mathrm{X}_{1} \mathrm{X}_{2}-0.151 \mathrm{X}_{1} \mathrm{X}_{3}+0.031 \mathrm{X}_{2} \mathrm{X}_{3} /$ / Interactive effects

$-0.418 \mathrm{X}_{1}{ }^{2}-0.363 \mathrm{X}_{2}{ }^{2}-0.278 \mathrm{X}_{3}{ }^{2} / /$ Quadratic effects (10)
Multivariate analysis (table 4) highlighted that linear variables such as wheat bran $\mathrm{X}_{1}$, and soybean meal $\mathrm{X}_{2}$ were significant $(* \mathrm{P}<0.01)$ while an additional carbon source, DPP, $\mathrm{X}_{3}\left({ }^{*} \mathrm{P}<0.01\right)$ was shown to be less impact on enzyme production.

Key outcome from two-way interactions was cooperation between carbon sources, $\mathrm{X}_{1} \mathrm{X}_{3}$, for growth as well as enzyme production $\left({ }^{*} \mathrm{P}<0.05\right)$ (Fig.5b). All three quadratic effects: $\mathrm{X}_{1}{ }^{2}, \mathrm{X}_{2}{ }^{2}, \mathrm{X}_{3}{ }^{2}\left({ }^{*} \mathrm{P}<0.01\right)$ were significant and negative coefficients had indicated that higher levels of $X_{1}, X_{2}, X_{3}$ would reduce response. Computed F-value (Fisher's Statistical Test: 29.26) from ANOVA table (table 5) was an indication of better fitness of polynomial model to experimental data from design matrix $\left({ }^{*} \mathrm{P}<0.001\right)$ (table 3). Multiple correlation coefficient $\left(\mathrm{R}^{2}: 99.06 \%\right)$ had enlighten that the second order polynomial model could explain $99.06 \%$ of variability in the response and only $0.094 \%$ of the total variations were not explained by the model. Variations in predicted $\mathrm{R}^{2}(98.13 \%)$ was corrected by adjusted $\mathrm{R}^{2}$ (94.78\%), both were suggesting a high significance model used for analyzing the data. The predicted results of RSM were confirmed by experimental verification. For this, fermentation was carried out with the above mentioned optimized medium and resultant response of fermentation was observed as $815.279 \mathrm{U} / \mathrm{g}$ $( \pm 12.48 \mathrm{U} / \mathrm{g})$ which was in accordance with predicted value. 
Table 4: Results of regression analysis of the second order polynomial model with MATLAB (R2012a)

\begin{tabular}{|c|c|c|c|c|}
\hline & Terms & Coefficient & Standard error & P value \\
\hline Intercept & - & 807.83 & 32.60 & $<0.01$ (Significant) \\
\hline Wheat bran $\left(\mathrm{X}_{1}\right)$ & Linear term & 219.04 & 19.96 & $<0.01$ (Significant) \\
\hline Soybean meal $\left(\mathrm{X}_{2}\right)$ & & 87.46 & 19.96 & $<0.01$ (Significant) \\
\hline Dried potato peel $\left(\mathrm{X}_{3}\right)$ & & -13.55 & 19.96 & 0.527 \\
\hline $\mathrm{X}_{1} \mathrm{X}_{2}$ & Interaction terms & 29.37 & 28.23 & 0.345 \\
\hline $\mathrm{X}_{1} \mathrm{X}_{3}$ & & -83.42 & 28.23 & 0.031 \\
\hline $\mathrm{X}_{2} \mathrm{X}_{3}$ & & 19.24 & 28.23 & 0.525 \\
\hline $\mathrm{X}_{1}^{2}$ & Quadratic terms & -208.57 & 29.38 & $<0.01$ (Significant) \\
\hline $\mathrm{X}_{2}^{2}$ & & -200.52 & 29.38 & $<0.01$ (Significant) \\
\hline $\mathrm{X}_{3}{ }^{2}$ & & -169.52 & 29.38 & $<0.01$ (Significant) \\
\hline
\end{tabular}

Summary of ANOVA for biomass was given in table 6 which indicated that biomass concentration was well described by proposed polynomial model given in Eq.10 (F-Value: 36.612).

Table 5: Analysis of variance for the fitted second order regression model for acid protease activity (MS Excel-7)

\begin{tabular}{|c|c|c|c|c|c|}
\hline & Df (Degrees of freedom) & SS(Sum of squares) & MS(Mean of squares) & F(Fischer's test value) & P value (Probability value) \\
\hline Regression & 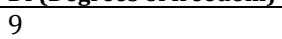 & 839807.91 & 93311.99 & 29.25 & 0.0008 \\
\hline Residual & 5 & 15945.74 & 3189.15 & & \\
\hline Total & 14 & 855753.60 & & & \\
\hline
\end{tabular}

Table 6: Analysis of variance for the fitted second order regression model-Growth of Aspergillus spp

\begin{tabular}{lllll}
\hline & Df (Degrees of freedom) & SS (Sum of squares) & MS (Mean of squares) & F(Fischer's test value) \\
Regression & 9 & 2.460 & 0.273 & 36.612 \\
Residual & 5 & 0.037 & 0.007 & \\
Total & 14 & 2.497 & & 0.005 \\
\hline
\end{tabular}

Multiple R: 99.25\%; R² ${ }^{2}$ : $98.50 ; R^{2}$ adj: 95.81

Some of the previous studies used similar approach of sequential steps of PBD followed by RSM for optimization of both acid and alkaline proteases production from various microbial sources [6, 7, 26-30]. Acid protease activity from Aspergillus niger reported in present study was comparable with earlier studies of [4 (2500 U/l), 7 (183.13 U/ml), 25 (577 U/ml), 31 (148.28 U/g)]. However, the highest acid protease activity of $8.93 \times 10^{5} \mathrm{U} / \mathrm{g}$ from Aspergillus oryzae from wheat bran was achieved by [6]. Ligno-cellulosic materials, wheat bran and DPP were evaluated as carbon sources for the maximum yield of acid protease in the current study. Similarly, previous report [31] revealed that agro industrial waste, sugarcane bagasse, was a suitable substrate for alkaline protease from Bacillus spp. through statistical method. In addition, another study [32] have reported that agro residues/wastes can be utilized as low cost materials for production of enzymes, biofuel, organic and amino acids there by environmental pollution is reduced. On the same traits, corncobs and coffee pulp waste were tested for alkaline protease optimization by BBD and observed the maximum yield of $920 \mathrm{U} / \mathrm{ml}$ [33].

Nitrogen source plays an important role in the production of protease. Therefore, the present study revealed that soybean meal was proved to be the potential nitrogen source. Similarly, protease production media were designed with sole nitrogen source, peptone, and other factors ( $\mathrm{pH}$ and moisture content) and achieved an

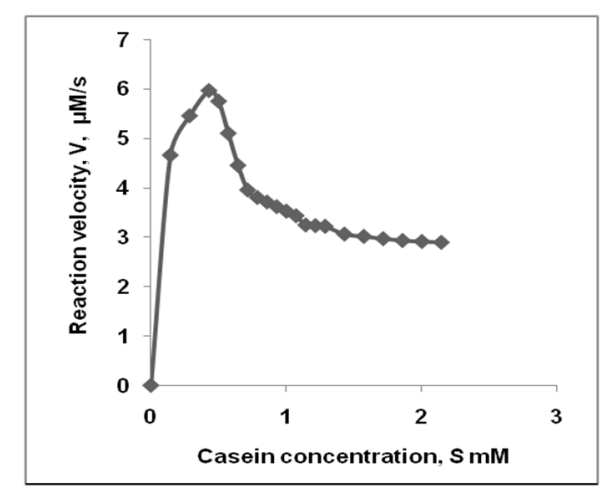

Fig. 7a: Plot showing the dependency of velocity on S-Deviation from rectangular behavior represented by Michaelis-Menten plot enzyme activity of $94.30 \mathrm{U} / \mathrm{ml}$ from Penicillium citrinum, isolated from fermented fish sauce [29].

\section{Partial casein inhibition kinetics}

In the present work we obtained maximum yield of enzyme through RSM method. Further study was carried out to achieve better yield with casein as assay substrate. In order to find out of suitable concentration of substrate on protease activity, the effect of substrate concentration in a range of 0.1 to $2.2 \mathrm{mmol}$ was studied. The velocity of caseinolysis by crude acid protease was shown by Michaelis-Menten plot (fig. 7a) and Line weaver-Burk plot (Fig.7b). It was noticed that velocity had deviated from normal rectangular hyperbola to decreased pattern at excess casein and it was due to partial SI. Experimental velocity of casein hydrolysis reached to a maximum velocity of 5.956 $\mu \mathrm{M} / \mathrm{s}$ when casein concentration range is 0 to $0.4 \mathrm{mmol}$ and then reduced to $2.89 \mu \mathrm{M} / \mathrm{s}$ beyond $0.4 \mathrm{mmol}$. It was also noticed that a linear increase in velocity up to $0.4 \mathrm{mmol}$ of casein concentration and an immediate decrease in velocity was observed till $1.1 \mathrm{mmol}$ of concentration. Later the velocity reached to a steady value even the increase in substrate concentration (fig. 7a). Similar behavior for phosphofructokinase was observed [18] and the authors were described this trend was due to partial SI. In addition, the biological significance of SI was well illustrated for various biocatalysts [16].

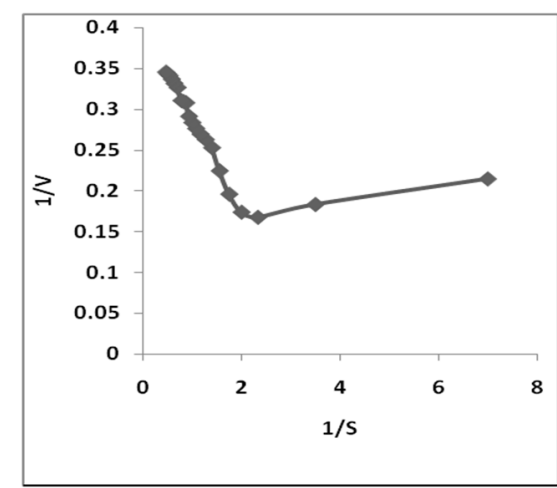

Fig. 7b: Display of non-linear behavior by Lineweaver-Burk plot 
As mathematical models of normal competitive, non-competitive, and uncompetitive inhibition kinetics will not fit to present study, another simple proposed model of [18] and Andrew's model were employed to explain the impact of SI on enzyme velocity. For this purpose, a plot of $1 / \mathrm{V}$ vs. 1/S at lower casein (fig. 8) was used to calculate Vmax and dissociation constant for ES complex, $\mathrm{K}_{1}$, from its slope and intercept as $6.849 \mu \mathrm{M} / \mathrm{s}$ and $0.062 \mathrm{mmol}$. At lower casein amounts, substrate (S) binds to the active site of acid protease (E) forms ES. Without inhibition, complex ES dissociates into product (P) with lower concentrations of casein and theoretical Vmax was obtained (Eq.3 and Eq. 4).

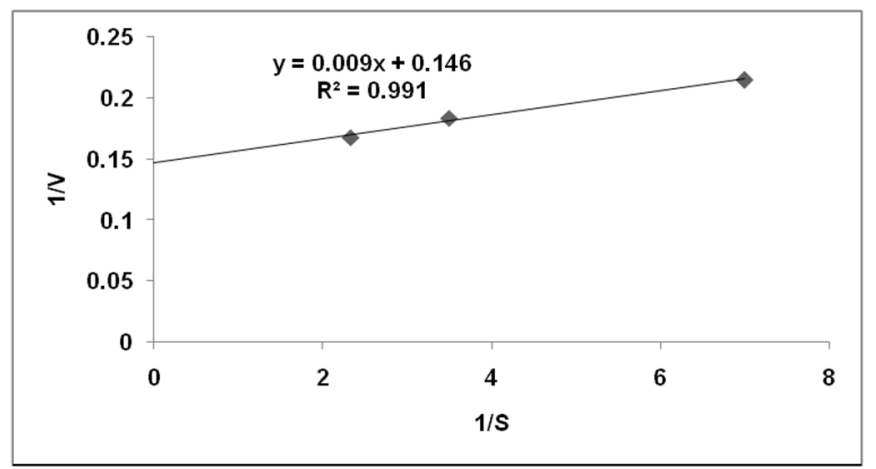

Fig. 8: Normal trend of double reciprocal graph for calculation on maximum velocity of reaction at lower concentrations of casein (Vmax: $6.849 \mu \mathrm{M} / \mathrm{s}$ and $\left.\mathrm{K}_{1}=0.062 \mathrm{mmol}\right)$

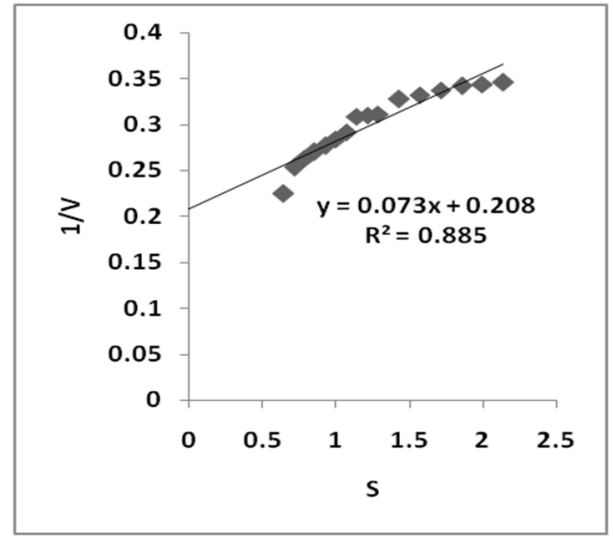

Fig. 9a: Plot of variation of reaction velocity with higher casein concentration (Model1: Vmax: $4.807 \mu \mathrm{M} / \mathrm{s}$ and Dissociation constant for SES $K_{N}=2.849 \mathrm{mmol}$ )
The most important parameter for SI was determination of dissociation constant for SES complex, $\mathrm{K}_{\mathrm{N}}$ which was found to be 2.849 mmol (Fig.9a-Model 1) and the same was $0.659 \mathrm{mmol}$. (Fig.9b-Model 2 ). It was understood that both above mentioned models were satisfactory to explain the modeling of SI. It was understood that promised value of $\mathrm{K}_{\mathrm{N}}$ at higher substrate concentration was explained the role of SES complex on enzyme velocity. Same effect was shown of substrate inhibition (Eq. 3), excess amount of casein further binds to complex ES then forms more complicated complex SES. Especially in partial substrate inhibition, dissociation of this complex is much slower than ES complex and reduces the velocity of reaction. This was confirmed with reduced Vmax from: 6.849 (Fig.8) to $4.807 \mu \mathrm{M} / \mathrm{s}$ (fig. 9a). Further reaction rate constant ratio $\mathrm{k}_{4} / \mathrm{k}_{2}$, was computed as 0.233 from the intercept of $\mathrm{V} /(\mathrm{Vmax}-\mathrm{V})$ vs. $1 / \mathrm{S}$ (Fig.9b). Rate constant ratio for partial SI must be less than $1\left(\mathrm{k}_{4} / \mathrm{k}_{2<1}\right)$ [18]. Reported value of $\mathrm{k}_{4} / \mathrm{k}_{2}$ had confirmed that velocity of hydrolysis of casein was inhibited by partial casein inhibition. Model 2 was the better fit to experimental data reaction rate with casein as $\mathrm{R}^{2}$ : $90.5 \%$ (fig. 9b). Enzymatic kinetic studies were performed for detergent-compatible protease from Aspergillus terreus and reported kinetic parameters were Vmax: 12.8 $\mathrm{U} / \mathrm{ml}$ and $\mathrm{Km}$ of $5.4 \mathrm{mg} / \mathrm{ml}[34]$.

\section{CONCLUSION}

Present study had revealed that the statistical methodology could be adopted easily for the design of suitable medium for the optimal production of acid protease with low cost substrates in SSF against

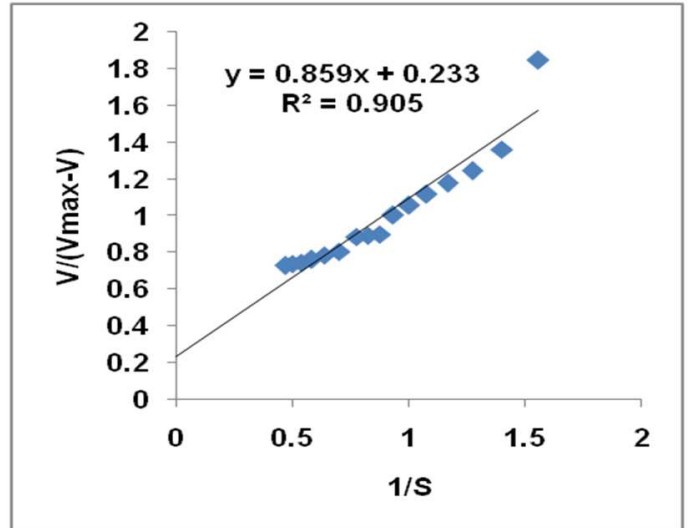

Fig. 9b: Display of velocity ratio as function of inverse higher casein concentration (Model 2 Rate constant ratio, $\mathbf{k}_{4} / \mathbf{k}_{2}$, from intercept was 0.233 and Dissociation constant for $S E S, K_{\mathrm{N}}$ from slope $=0.659 \mathrm{mmol}$ ]

OVAT. PBD had allowed the quick identification of significant solid substrates and BBD determined the combination of carbon and nitrogen supplements for better protease activity in simple experiments. The experimental data of RSM was best fit to predicted quadratic model. Kinetic studies on partial casein inhibition were understood with simple reaction mechanisms. Both above mention models of SI were very useful in understanding of deviation of rate of enzymatic reaction with substrate. Calculation of inhibitory constant, $\mathrm{K}_{\mathrm{N}}$ and rate constant ratio $\left(\mathrm{k}_{4} / \mathrm{k}_{2}\right)$ was more useful in substrate inhibition.

\section{ABBREVIATION}

ANOVA: Analysis of variance, BBD: Box Behnken design, DPP: Dried potato peel, OVAT: One variable at a time, PBD: PlackettBurman design, RSM: Response Surface Methodology, $\mathrm{R}^{2}$ Adj: Adjusted R square, $\mathrm{R}^{2}$ Pre: Predicted R square, Spp.: Species, SSF: Solid state fermentation

\section{ACKNOWLEDGEMENT}

The authors express thank to Department of Biotechnology, Sri Vidyanikethan Engineering College and Department of Virology, Sri Venkateswara University, Tirupati, for providing laboratory facilities to perform the present experimental study.

\section{AUTHORS CONTRIBUTIONS}

Radha Seela1: Carried out the Research work. 
Narasimha Golla²: Provided guidance, critical review, revision and corresponding this article.

Sridevi Ayla: Helped while caring the experiments.

Prasad NBL: Co-supervisor of this work.

\section{CONFLICT OF INTERESTS}

The authors declare that they have no conflict of interest

\section{REFERENCES}

1. Azzam A, Ramzi AAA, Avnish P, Nor Zalina O, Roslinda AM, El Enshasy HA. Biotechnological aspects and pharmaceutical applications of bacterial proteases. Pharm Lett 2017;9:9-20.

2. Rao MB, Tanksale AM, Ghatge MS, Deshpande VV. Molecular and biotechnological aspects of microbial proteases. Microbiol Mol Biol Rev 1998;62:597-635.

3. Souza PM, Bittencourt MLA, Caprara CC, Freitas M. Biotechnology perspective of fungal proteases-a review. Braz J Microbiol 2015;46:337-46.

4. Venkat KS, Ashok Rao, Joshua RN. Screening, media optimization and partial purification of protease by Trichosporonjaponicum VITVK1. Int J Pharm Pharm Sci 2015; 7:187-91.

5. Kalaskar VV, Narayanan K, Subrahmanyam VM, Rao VJ. Partial characterisation and therapeutic application of protease from a fungal species. Indian Drugs 2012;49:42-6.

6. Viswanatha KS, Appu Rao AG, Singh SA. Acid protease production using solid-state fermentation by Aspergillus oryzae MTCC 5341: optimization of process parameters. J Indian Microbial Biotechnol 2009;37:129-38.

7. Siala R, Frikha F, Mhamdi S, Nasri M, Sellami AK. Optimization of acid protease production by Aspergillus niger I1 on shrimp peptone using statistical experimental design. Sci World J 2012;11. DOI:10.1100/2012/564932.

8. Djamel C, Ali T, Nelly C. Acid protease production by isolated species of Penicillium. Eur J Sci Res 2009;25:469-77.

9. Soares VF, Castilho LR, Bon EP, Freire DM. High-yield Bacillus subtilis for protease production by solid-state fermentation. Appl Biochem Biotechnol 2005;121-124:311-9.

10. Aravindhan R, Anbumathi P, Viruthagiri T. Evaluation of medium components by Plackett-Burman statistical design for lipase production by Candida rugosa and kinetic modeling. Chinese J Biotechnol 2008;24:436-44.

11. Vasanthabharathi V, Shellarani S, Lakshminarayanan $R$, Jayalakshmi S. Statistical optimization and production of protease from estuarine Citrobacterdiversus. Int Res J Biol Sci 2016;5:18-25.

12. Xiong ZQ, Tu XR, Tu GQ. Optimization of medium composition for actinomycin X2 production by Streptomyces spp. JAU4234 using response surface methodology. J Indian Microbiol Biotechnol 2008;35:729-34.

13. Wang Q, Yanhua H, Zhong X, Jinlai M, Guangyou L. Optimization of cold-active protease production by the psychrophilic bacterium Colwellia sp. with response surface methodology. Bioresour Technol 2008;99:1926-31.

14. Hong G, Mei L, Jintao L, Huanqin D, Xianlong Z, Xiangyang L, et al. Medium optimization for the production of avermectin B1 a by Streptomyces avermitilis 14-12A using response surface methodology. Bioresour Technol 2009;100:4012-6.

15. Asis KM, Sudir KR. A statistical approach for the enhanced production of alkaline protease showing the fibrinilytic activity from a newly isolated gram-negative Bacillus sp. strain AS-S20I. New Biotechnol 2011;28:182-9.
16. Reed MC, Anna L, Frederik NH. The biological significance of substrate inhibition: a mechanism with diverse functions. Bioessays 2010;32:422-9.

17. Nejad ZG, Soheila Y, Nazanin M, Bahareh S. Some investigations on protease enzyme production kinetics using Bacillus licheniformis BBRC 100053 and effects of inhibitors on protease activity. Int J Chem Engg 2014. http://dx.doi.org/ 10.1155/2014/394860

18. Yoshino M, Murakam K. Analysis of the substrate inhibition of complete and partial types. Springerplus 2015;4:292.

19. Radha S, Sridevi A, Himakiran BR, Nithya VJ, Prasad NBL, Narasimha G. Isolation and screening of proteolytic fungal cultures from soil contaminated with abattoir waste. Biochem BCAIJ 2012;6:226-30.

20. Lowry $\mathrm{OH}$, Rosebrough NJ, Farr AL, Randall RJ. Protein measurement with folin phenol reagent. J Biol Chem 1951; 193:265-75.

21. Shuler ML, Kargi F. Enzymes. A text book of Bioprocess Engineering-Basic Concepts. 2 ${ }^{\text {nd }}$ Edition. Pearson Education: India; 2003. p. 60-73.

22. Okpokwasili GC, Nweke CO. Microbial growth and substrate utilization kinetics. Afr J Biotechnol 2005;5:305-7.

23. Lu-E Shi, Guo-Qing Y, Xiao-Ying Z, Zhen-Xing T, Jian-Shu C, Wen-Yue $\mathrm{X}$, et al. Medium optimization for 5'-Phospshodiesterase production from Penicillium citrinumusing response surface methodology. Food Technol Biotechnol 2007;45:126-33.

24. Plackett RL, Burman JP. The design of optimum multifactorial experiments. Biometrica 1946;33:305-25.

25. Radha S, Sridevi A, Himakiran Babu R, Nithya VJ, Prasad NBL, Narasimha G. Medium optimization for acid protease production from Aspergillus sps. under solid state fermentation and mathematical modeling of protease activity. J Microbiol Biotechnol Res 2012;2:6-16.

26. Chauhan B, Gupta R. Application of statistical experimental design for optimization of alkaline protease production from Bacillus sp. RGR-14. Process Biochem 2004;39:2115-22.

27. Rajshree S, Rajni S. Statistical optimization of conditions for protease production from Bacillus sp. Acta Biologica Szegediensis 2014;54:35-141.

28. Govarthanan M, Lee J, Cho M, Seralathan K, Byung-Taek, O. Statistical optimization of alkaline protease production from brackish environment Bacillus sp. SKK 11 by SSF using horse gram husk. Preparative Biochem Biotechnol 2014;44:119-31.

29. Xiao Y, Wu D, Zhao S, Lin W, Gao X. Statistical optimization of alkaline protease production from Penicillium citrinumYL-1 under solid-state fermentation. Preparative Biochem Biotechnol 2015;45:447-62.

30. Kshetri P, Ningombam O, Ningombam DS. Optimization of alkaline protease production by alkaliphilic Bacillus sp. KW2 in low cost medium using statistical approaches. Appl Microbiol 2016;2:2.

31. Rathakrishnan P, Nagarajan P, Rajeshkannan R. Optimization of protease production by Bacillus licheniformisin sugarcane bagasse using statistical experimental design. Resin Biotechnol 2012;3:1-10.

32. Qureshi AS, Dahot UM. Production of proteases by Staphylococcus epidermidis EFRL using cost effective substrate (molasses) as a carbon source. Pakistan J Biotechnol 2009;6:55-60.

33. Kandasamy S, Muthusamy G, Balakrishnan S, Duraisamy S, Thangasamy S. Optimization of protease production from surface-modified coffee pulp waste and corncobs using Bacillus sp. by SSF. 3 Biotech 2016;6:167.

34. Niyonzima FN, More SS. Purification and characterization of detergent-compatible protease from Aspergillus terreus gr. 3 Biotech 2015;5:61-70. 